NASA/TM-2000-209891, Vol. 185

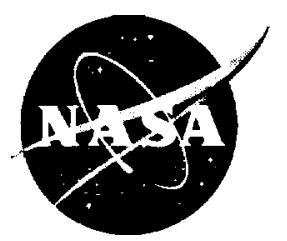

Technical Report Series on the Boreal Ecosystem-Atmosphere Study (BOREAS)

Forrest G. Hall and Andrea Papagno, Editors

\title{
Volume 185
}

\section{BOREAS TE-21 Daily Surface}

Meteorological Data

J. Kimball

National Aeronautics and

Space Administration

Goddard Space Flight Center

Greenbelt, Maryland 20771 


\section{The NASA STI Program Office ... in Profile}

Since its founding, NASA has been dedicated to the advancement of aeronautics and space science. The NASA Scientific and Technical Information (STI) Program Office plays a key part in helping NASA maintain this important role.

The NASA STI Program Office is operated by Langley Research Center, the lead center for NASA's scientific and technical information. The NASA STI Program Office provides access to the NASA STI Database, the largest collection of aeronautical and space science STI in the world. The Program Office is also NASA's institutional mechanism for disseminating the results of its research and development activities. These results are published by NASA in the NASA STI Report Series, which includes the following report types:

- TECHNICAL PUBLICATION. Reports of completed research or a major significant phase of research that present the results of NASA programs and include extensive data or theoretical analysis. Includes compilations of significant scientific and technical data and information deemed to be of continuing reference value. NASA's counterpart of peer-reviewed formal professional papers but has less stringent limitations on manuscript length and extent of graphic presentations.

- TECHNICAL MEMORANDUM. Scientific and technical findings that are preliminary or of specialized interest, e.g., quick release reports, working papers, and bibliographies that contain minimal annotation. Does not contain extensive analysis.

- CONTRACTOR REPORT. Scientific and technical findings by NASA-sponsored contractors and grantees.
- CONFERENCE PUBLICATION. Collected papers from scientific and technical conferences, symposia, seminars, or other meetings sponsored or cosponsored by NASA.

- SPECIAL PUBLICATION. Scientific, technical, or historical information from NASA programs, projects, and mission, often concerned with subjects having substantial public interest.

- TECHNICAL TRANSLATION. English-language translations of foreign scientific and technical material pertinent to NASA's mission.

Specialized services that complement the STI Program Office's diverse offerings include creating custom thesauri, building customized databases, organizing and publishing research results ... even providing videos.

For more information about the NASA STI Program Office, see the following:

- Access the NASA STI Program Home Page at http://www.sti.nasa.gov/STI-homepage.html

- E-mail your question via the Internet to help@sti.nasa.gov

- Fax your question to the NASA Access Help Desk at (301) 621-0134

- Telephone the NASA Access Help Desk at (301) 621-0390

- Write to: NASA Access Help Desk NASA Center for AeroSpace Information 7121 Standard Drive Hanover, MD 21076-1320 
NASA/TM-2000-209891, Vol. 185

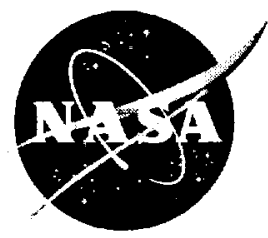

Technical Report Series on the Boreal Ecosystem-Atmosphere Study (BOREAS)

Forrest G. Hall and Andrea Papagno, Editors

\section{Volume 185}

\section{BOREAS TE-21 Daily Surface Meteorological Data}

John Kimball, University of Montana, Missoula

National Aeronautic :tnd

Space Administration

Goddard Space Flight Center

Greenbelt, Maryland 2(177) 
Available from:

NASA Center for AeroSpace Information

7121 Standard Drive

Hanover, MD 21076-1320

Price Code: A 17
National Technical Information Service 5285 Port Royal Road Springfield, VA 22161

Price Code: A 10 


\title{
BOREAS TE-21 Daily Surface Meteorological Data
}

\author{
John Kimball
}

\section{Summary}

The BOREAS TE-21 team collected data sets in support of its efforts to characterize and interpret information on the meteorology of boreal forest areas. Daily meteorological data were derived from half-hourly BOREAS TF and AMS mesonet measurements collected in the SSA and NSA for the period of 01-Jan-1994 until 31-Dec-1994. The data were stored in tabular ASCII files.

\section{Table of Contents}
1) Data Set Overview
2) Investigator(s)
3) Theory of Measurements
4) Equipment
5) Data Acquisition Methods
6) Observations
7) Data Description
8) Data Organization
9) Data Manipulations
10) Errors
11) Notes
12) Application of the Data Set
13) Future Modifications and Plans
14) Software
15) Data Access
16) Output Products and Availability
17) References
18) Glossary of Terms
19) List of Acronyms
20) Document Information

\section{Data Set Overview}

\subsection{Data Set Identification}

BOREAS TE-21 Daily Surface Meteorological Data

\subsection{Data Set Introduction}

Daily meteorological data were assembled from 1994 half-hourly BOReal Ecosystem-Atmosphere Study (BOREAS) Tower Flux (TF) and Automatic Meteorological Station (AMS) mesonet measurements collected in the Southern Study Area (SSA) and Northern Study Area (NSA).

\subsection{Objective/Purpose}

The purpose of this data set is to provide a full-year meteorological data base for stand hydrologic and biogeochemical model simulations at the BOREAS TF sites. 


\subsection{Summary of Parameters}

Each data set contains the date, total incoming photosynthetically active radiation (PAR), total incoming solar radiation (direct + diffuse), total incoming longwave radiation, maximum daily air temperature, minimum daily air temperature, average daily air temperature, average daily windspeed, average daily relative humidity, daily precipitation derived from tipping bucket and Belfort gauges, and an identification flag for precipitation.

\subsection{Discussion}

Half-hourly meteorological data were derived from $1994 \mathrm{TF}$ and AMS mesonet measurements. These data often contained temperature, wind, and humidity data at one or more heights. When data at more than one height were available, data were taken from the upper height that corresponded most closely with the top of the canopy or the upper level at which water and $\mathrm{CO}_{2}$ fluxes were measured. No attempt was made to adjust the data to account for differences in measurement heights.

Full-year half-hourly data files for each tower site were created by placing several adjacent tower site data files together in series. Missing values were then selected from adjacent data files with complete data for the same time period. Preceding data were always favored first in the selection process. The following series were used to create complete data files for each tower site:

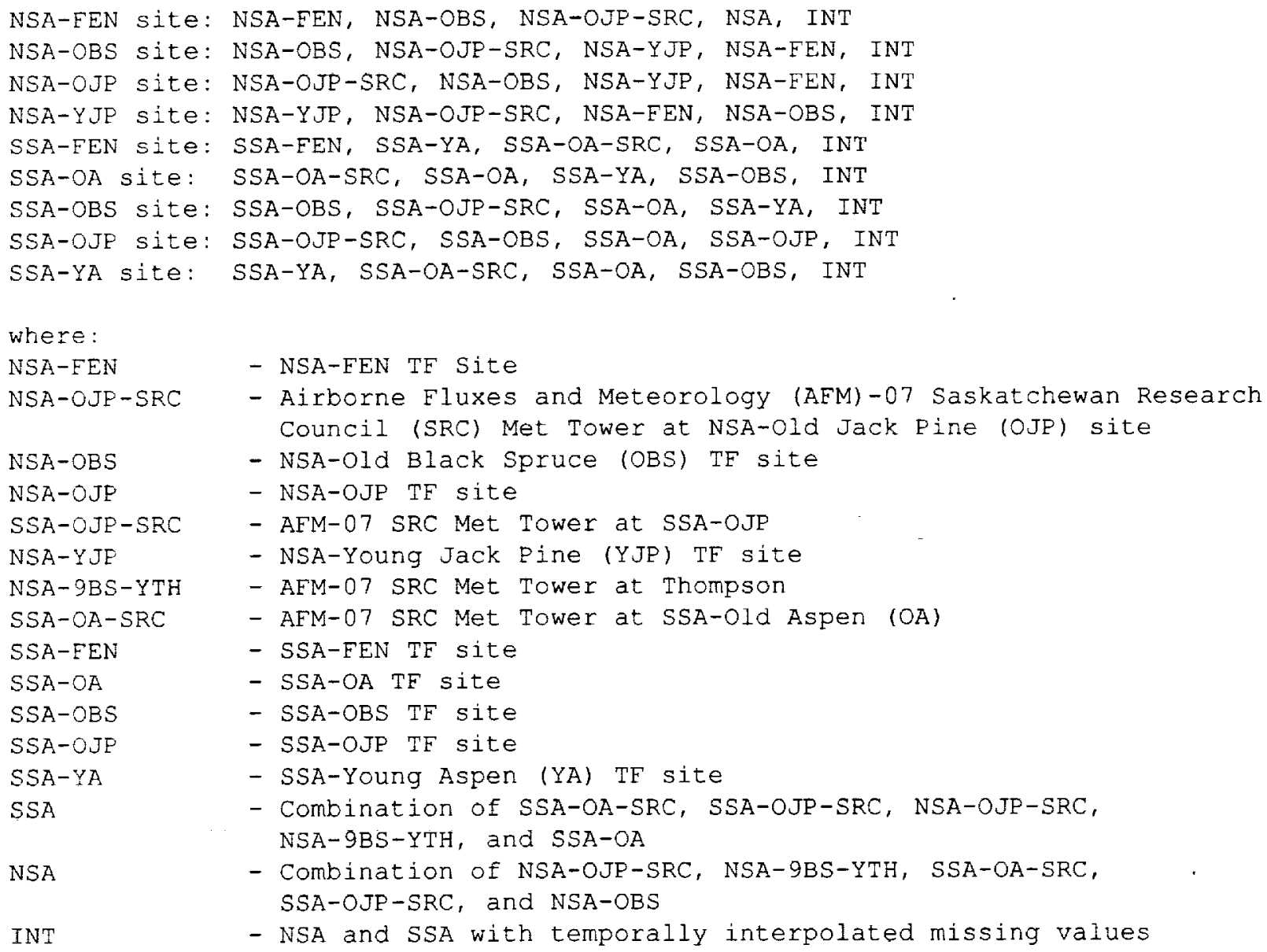

Longwave incoming radiation (lw) measurement data from the NSA-OJP AMS mesonet tower site (NSA-OJP-SRC) and the SSA-OJP AMS mesonet tower site (SSA-OJP-SRC) were used to represent longwave radiation characteristics for tower sites in the BOREAS NSA and SSA, respectively. Missing values were estimated using a multiple linear regression fit between measured longwave radiation, estimated clear-sky longwave radiation, and relative humidity: 
Iw.est $=80.3855+0.7521 * \mathrm{lw} . \mathrm{clr}+0.4525 * \mathrm{RH}$

where: $\quad$ lw.est $=$ estimated lw irradiance $\left(\mathrm{W} / \mathrm{m}^{2}\right)$

lw.clr $=$ estimated clear-sky lw irradiance $\left(\mathrm{W} / \mathrm{m}^{2}\right)$

$\mathrm{RH}=$ measured relative humidity $(\%)$

Iw.clr was estimated from air temperature and relative humidity measurements using an approach described by Marks and Dozier (1979).

Incoming solar radiation and PAR files were created by combining NSA-OJP-SRC,

NSA-9BS-YTH, SSA-OA-SRC, SSA-OJP-SRC, and NSA-OBS files. Missing solar radiation that was not available was estimated as (PAR * 2.0) and missing PAR radiation as $50 \%$ of the solar radiation value. Daily data were derived from the complete half-hourly data files created for each tower site. Daily tipping bucket and Belfort precipitation data were combined at each site. Precipitation data from adjacent tower sites were then used to fill in missing values. Each daily precipitation value is flagged with the identification flag of the tower site file where it came from.

The 1994 full-year half-hourly data used to create the daily data files are available upon request from Terrestrial Ecology (TE)-21.

\subsection{Related Data Sets}

BOREAS AFM-07 SRC Surface Meteorological Data

BOREAS TE-05 Surface Meterological and Radiation Data

BOREAS TF-01 SSA-OA Tower Flux and Meteorological Data

BOREAS TF-02 SSA-OA Tower Flux and Meteorological Data

BOREAS TF-03 NSA-OBS Tower Flux, Meteorological, and Soil Temperature Data

BOREAS TF-04 SSA-OJP Flux and Meteorology Data

BOREAS TF-05 SSA-OJP Tower Flux and Meteorological Data

BOREAS TF-06 SSA-YA Surface Energy Flux and Meteorological Data

BOREAS TF-09 SSA-OBS Tower Flux, Meteorological, and Soil Temperature Data

BOREAS TF-10 NSA-Fen Tower Flux and Meteorological Data

BOREAS TF-11 SSA-Fen Tower Flux and Meteorological Data

\section{Investigator(s)}

\subsection{Investigator(s) Name and Title}

Dr. Steve Running

Dr. John Kimball

\subsection{Title of Investigation}

Simulation of Boreal Ecosystem Carbon and Water Budgets: Scaling from Local to Regional Extents

\subsection{Contact Information}

\section{Contact 1:}

John Kimball

University of Montana

Missoula, MT 59812

(406) 243-5616

(406) 243-4510 (fax)

johnk@ntsg.umt.edu 
Contact 2:

Andrea Papagno

Raytheon ITSS

NASA GSFC

Code 923

Greenbelt, MD 20771

(301) 286-3134

(301) 286-0239 (fax)

Andrea.Papagno@gsfc.nasa.gov

\section{Theory of Measurements}

None given.

\section{Equipment}

\subsection{Sensor/Instrument Description}

\subsubsection{Collection Environment}

Data were derived from $1994 \mathrm{TF}$ and AMS mesonet measurements. Refer to the documentation for the data sets listed in Section 1.6 for further information.

\subsubsection{Source/Platform}

None given.

\subsubsection{Source/Platform Mission Objectives}

None given.

\subsubsection{Key Variables}

Each data set contains the date, total incoming PAR, total incoming solar radiation (direct + diffuse), total incoming longwave radiation, maximum daily air temperature, minimum daily air temperature, average daily air temperature, average daily windspeed, average daily relative humidity, daily precipitation derived from tipping bucket and Belfort gauges, and an identification flag for precipitation.

\subsubsection{Principles of Operation}

None given.

\subsubsection{Sensor/Instrument Measurement Geometry}

None given.

\subsubsection{Manufacturer of Sensor/Instrument}

None given.

\subsection{Calibration}

None given.

\subsubsection{Specifications}

None given. 


\subsubsection{Tolerance}

None given.

\subsubsection{Frequency of Calibration}

None given.

\subsubsection{Other Calibration Information \\ Not applicable.}

\section{Data Acquisition Methods}

See Section 1.5.

\section{Observations}

\subsection{Data Notes}

The 1994 full-year half-hourly data used to create the daily data files are available upon request from TE-21.

1994 full-year 15 -minute data for the TF sites have also been created by BOREAS Information System (BORIS) staff.

\subsection{Field Notes \\ None given.}

\section{Data Description}

\subsection{Spatial Characteristics}

None given.

\subsubsection{Spatial Coverage}

The measurement sites and associated North American Datum of 1983 (NAD83) coordinates are:

- NSA-FEN flux tower, site id T7S1T, Lat/Long: $55.91481^{\circ} \mathrm{N}, 98.42072^{\circ} \mathrm{W}$, Universal Transverse Mercator (UTM) Zone 14, N: 6,196,749.6, E: 536,207.9.

- $\quad$ NSA-OBS flux tower, site id T3R8T, Lat/Long: $55.88007^{\circ} \mathrm{N}, 98.48139^{\circ} \mathrm{W}$, UTM Zone 14 , $\mathrm{N}: 6,192,853.4, \mathrm{E}: 532,444.5$.

- NSA-OJP-SRC and NSA-OJP flux tower, site id T7Q8T, Lat/Long: $55.92842^{\circ} \mathrm{N}, 98.62396^{\circ}$ W, UTM Zone 14, N: 6,198,176.3, E: 523,496.2.

- $\quad$ NSA-YJP flux tower, site id T8S9T, Lat/Long: $55.89575^{\circ} \mathrm{N}, 98.28706^{\circ} \mathrm{W}$, UTM Zone 14 , N: 6,194,706.9, E: 544,583.9.

- $\quad$ SSA-FEN flux tower, site id F0L9T, Lat/Long: $53.80206^{\circ} \mathrm{N}, 104.61798^{\circ} \mathrm{W}$, UTM Zone 13, $\mathrm{N}: 5,961,566.6, \mathrm{E}: 525,159.8$.

- SSA-OA-SRC and SSA-OA flux tower, site id C3B7T, Lat/Long: $53.62889^{\circ} \mathrm{N}, 106.19779^{\circ}$ W, UTM Zone 13, N: 5942899.9, E: 420790.5 .

- $\quad$ SSA-OBS flux tower, site id G8I4T, Lat/Long: $53.98717^{\circ} \mathrm{N}, 105.11779^{\circ} \mathrm{W}$, UTM Zone 13 , $\mathrm{N}: 5,982,100.5, \mathrm{E}: 492,276.5$.

- $\quad$ SSA-OJP-SRC and SSA-OJP flux tower, site id G2L3T, Lat/Long: $53.91634^{\circ} \mathrm{N}$, $104.69203^{\circ} \mathrm{W}$, UTM Zone 13, N: 5,974,257.5, E: 520,227.7.

- $\quad$ SSA-YA flux tower, site id DOH4T, Lat/Long: $53.65601^{\circ} \mathrm{N}, 105.32314^{\circ} \mathrm{W}$, UTM Zone 13, $\mathrm{N}: 5,945,298.9, \mathrm{E}: 478,644.1$.

- NSA-9BS-YTH mesonet tower, Station identifier number 5062922, Lat/Long: $55.8^{\circ} \mathrm{N}$, $97.87^{\circ} \mathrm{W}$, UTM Zone 14, N: 6,184,839, E: 570,580. 


\subsubsection{Spatial Coverage Map}

Not available.

\subsubsection{Spatial Resolution}

The data are intended to represent the surface meteorological conditions at the given sites. Due to the substitution and interpolation performed to compile complete data records for each site, users should use their best judgment in interpreting the spatial nature of the data.

\subsubsection{Projection}

Not applicable.

\subsubsection{Grid Description}

Not applicable.

\subsection{Temporal Characteristics}

\subsubsection{Temporal Coverage}

Daily data were collected from 01-Jan-1994 until 31-Dec-1994.

\subsubsection{Temporal Coverage Map}

None given.

\subsubsection{Temporal Resolution}

The data represent daily surface meteorological conditions.

\subsection{Data Characteristics}

\subsubsection{Parameter/Variable}

The parameters contained in the data files on the CD-ROM are:

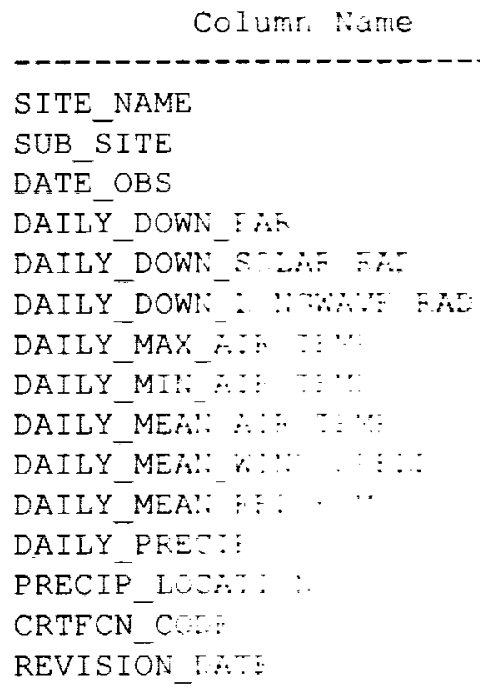




\subsubsection{Variable Description/Definition}

The descriptions of the parameters contained in the data files on the CD-ROM are:

\begin{tabular}{|c|c|}
\hline Column Name & Description \\
\hline SITE_NAME & $\begin{array}{l}\text { The identifier assigned to the site by BOREAS, } \\
\text { in the format SSS-TTT-CCCCC, where SSS identifies } \\
\text { the portion of the study area: NSA, SSA, REG, } \\
\text { TRN, and TTT identifies the Cover type for the } \\
\text { site, } 999 \text { if unknown, and CCCCC is the identifier } \\
\text { for site, exactly what it means will vary with } \\
\text { site type. }\end{array}$ \\
\hline SUB_SITE & $\begin{array}{l}\text { The identifier assigned to the sub-site by } \\
\text { BOREAS, in the format GGGGG-IIIII, where GGGGG is } \\
\text { the group associated with the sub-site } \\
\text { instrument, e.g. HYD06 or STAFF, and IIIII is the } \\
\text { identifier for sub-site, often this will refer to } \\
\text { an instrument. }\end{array}$ \\
\hline $\begin{array}{l}\text { DATE_OBS } \\
\text { DAILY_DOWN_PAR }\end{array}$ & $\begin{array}{l}\text { The date on which the data were collected. } \\
\text { The daily downwelling photosynthetically active } \\
\text { radiation. }\end{array}$ \\
\hline DAILY_DOWN_SOLAR_RAD & The daily downwelling solar radiation. \\
\hline DAILY_DOWN_LONGWAVE_RAD & The daily downwelling longwave radiation. \\
\hline DAILY_MAX_AIR_TEMP & The daily maximum air temperature. \\
\hline DAILY_MIN_AIR_TEMP & The daily minimum air temperature. \\
\hline DAILY_MEAN_AIR_TEMP & The mean daily air temperature. \\
\hline DAILY_MEAN_WIND_SPEED & The mean daily wind speed. \\
\hline DAILY_MEAN_REL_HUM & The mean daily relative humidity. \\
\hline DAILY_PRECIP & The daily precipitation. \\
\hline PRECIE_LOCATION & $\begin{array}{l}\text { The identification of the tower site file where } \\
\text { the precipitation data came from. }\end{array}$ \\
\hline CRTFCN_CODE & $\begin{array}{l}\text { The BOREAS certification level of the data. } \\
\text { Examples are CPI (Checked by PI), CGR (Certified } \\
\text { by Group), PRE (Preliminary), and CPI-??? (CPI } \\
\text { but questionable). }\end{array}$ \\
\hline REVISION_DA? & $\begin{array}{l}\text { The most recent date when the information in the } \\
\text { referenced data base table record was revised. }\end{array}$ \\
\hline
\end{tabular}

\subsubsection{Unit of Measurement}

The measurement units for the parameters contained in the data files on the CD-ROM are:

\begin{tabular}{|c|c|}
\hline Column Name & Units \\
\hline SITE NAME & [none] \\
\hline SUB_SITE & [none] \\
\hline DATE_OBS & {$[D D-M O N-Y Y]$} \\
\hline DAILY_DOWN_PAR & [MegaJoules] [meters^ ${ }^{\wedge} 2$ ] [day^-1] \\
\hline DAILY_DOWN_SOLAR_RAD & [MegaJoules] [meters^ -2$]\left[\right.$ day $\left.^{\wedge}-1\right]$ \\
\hline DAILY_DOWN_LONGWAVE_RAD & [MegaJoules] [meters^ $\left.{ }^{\wedge}-2\right]\left[\mathrm{day}^{\wedge}-1\right]$ \\
\hline DAILY MAX ĀIR TEMP & [degrees Celsius] \\
\hline DAILY_MIN_AIR_TEMP & [degrees Celsius] \\
\hline DAILY_MEAN & [degrees Celsius] \\
\hline DAILY_MEAN WIND_SPEED & {$[$ meters $][$ second^-1] } \\
\hline DAILY MEAN REL & [percent] \\
\hline
\end{tabular}

Page 7 
DAILY_PRECIP
PRECIP_LOCATION
CRTFCN_CODE
REVISION_DATE

\subsubsection{Data Source}

The sources of the parameter values contained in the data files on the CD-ROM are:

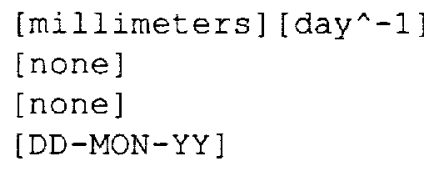

Column Name

SITE_NAME
SUB_SITE
DATE_OBS
DAILY_DOWN_PAR
DAILY_DOWN_SOLAR_RAD
DAILY_DOWN_LONGWAVE_RAD
DAILY_MAX_AIR_TEMP
DAILY_MIN_AIR_TEMP
DAILY_MEAN_AIR_TEMP
DAILY_MEAN_WIND_SPEED
DAILY_MEAN_REL_HUM
DAILY_PRECIP
PRECIP_LOCATION
CRTFCN_CODE
REVISION_DATE

Data Source

\subsubsection{Data Range}

The following table gives information about the parameter values found in the data files on the CD-ROM.

\begin{tabular}{|c|c|c|c|c|c|c|}
\hline Column Name & $\begin{array}{l}\text { Minimum } \\
\text { Data } \\
\text { Value }\end{array}$ & $\begin{array}{l}\text { Maximum } \\
\text { Data } \\
\text { value }\end{array}$ & $\begin{array}{l}\text { Missng } \\
\text { Data } \\
\text { Value }\end{array}$ & $\begin{array}{l}\text { Unrel } \\
\text { Data } \\
\text { Value }\end{array}$ & $\begin{array}{l}\text { Below } \\
\text { Detect } \\
\text { Limit }\end{array}$ & $\begin{array}{l}\text { Data } \\
\text { Not } \\
\text { cllctd }\end{array}$ \\
\hline-------------------1 & ------------- & 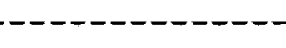 & ----- & ------- & ---- & $---\infty$ \\
\hline SITE_NAME & NSA-FEN-FLXTR & SSA-OJP-FLXTR & None & None & None & None \\
\hline SUB_SITE & 9TE21-METO1 & 9TE21-MET01 & None & None & None & None \\
\hline DATE_OBS & $01-J A N-94$ & $31-\mathrm{DEC}-94$ & None & None & None & None \\
\hline DAILY_DOWN_PAR & .122217 & 12.9 & None & None & None & None \\
\hline DAILY_DOWN SOLAR RAD & .26677 & 32.4 & None & None & None & None \\
\hline $\begin{array}{l}\text { DAILY_DOWN_LONGWAVE_ } \\
\text { RAD }\end{array}$ & 10.82358 & 32.5 & None & None & None & None \\
\hline DAILY_MAX_AIR_TEMP & -35.76 & 31.01 & None & None & None & None \\
\hline DAILY_MIN_AIR_TEMP & -39.99 & 19.2 & None & None & None & None \\
\hline DAILY_MEAN_AIR_TEMP & -37.279 & 23.607 & None & None & None & None \\
\hline $\begin{array}{l}\text { DAIIY_MEAN_WIND_ } \\
\text { SPEED }\end{array}$ & .0111565 & 7.13842 & None & None & None & None \\
\hline DAILY_MEAN_REI_HUM & 22.0516 & 99.074 & None & None & None & None \\
\hline DAIIY_PRECIP & 0 & 81.4 & None & None & None & None \\
\hline PRECIP_LOCATION & $N / A$ & $N / A$ & None & None & None & None \\
\hline CRTFCN_CODE & CPI & CPI & None & None & None & None \\
\hline REVISION_DATE & $14-J A N-99$ & $14-J A N-99$ & None & None & None & None \\
\hline
\end{tabular}




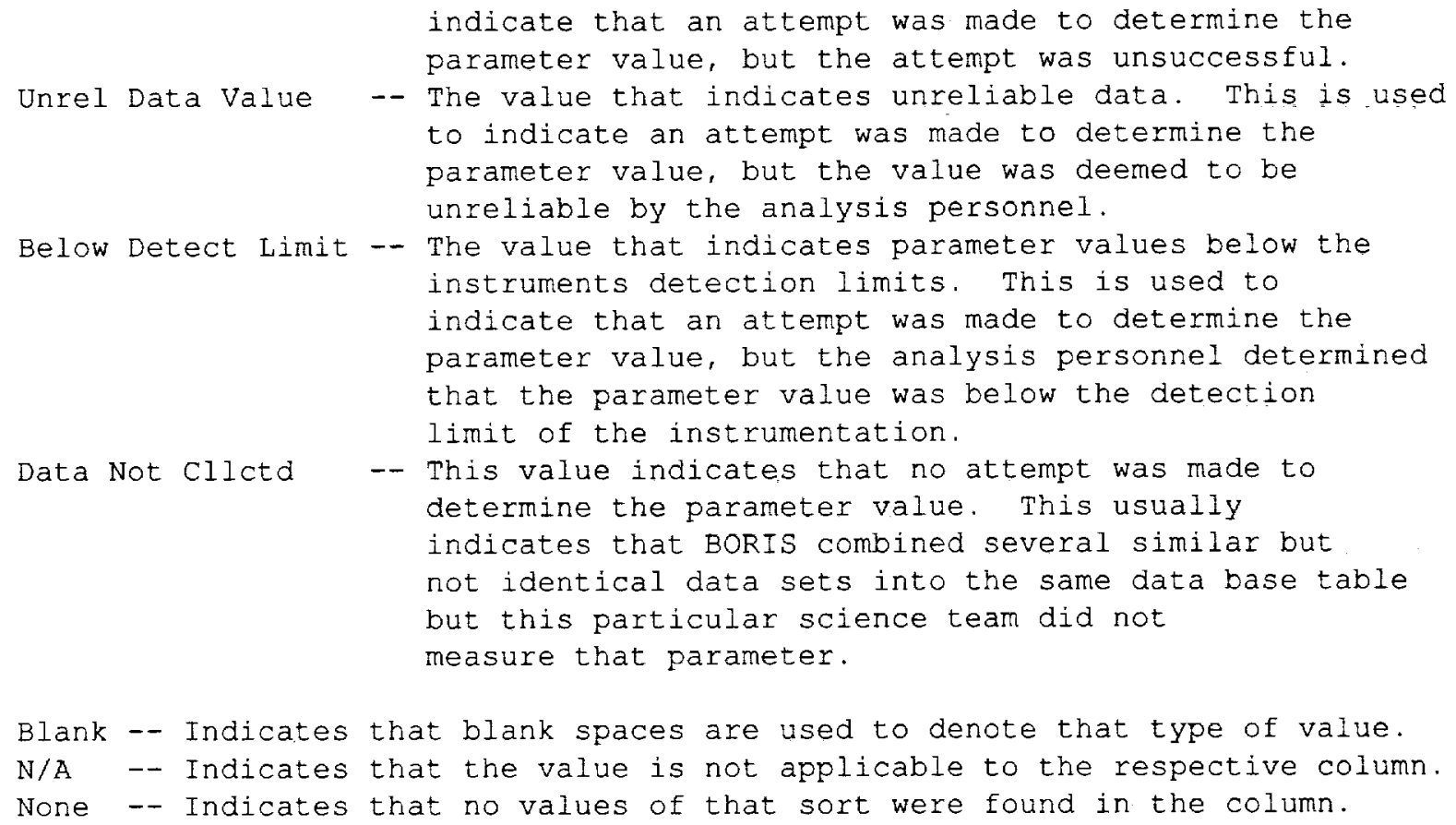

\subsection{Sample Data Record}

The following are wrapped versions of data record from a sample data file on the CD-ROM.

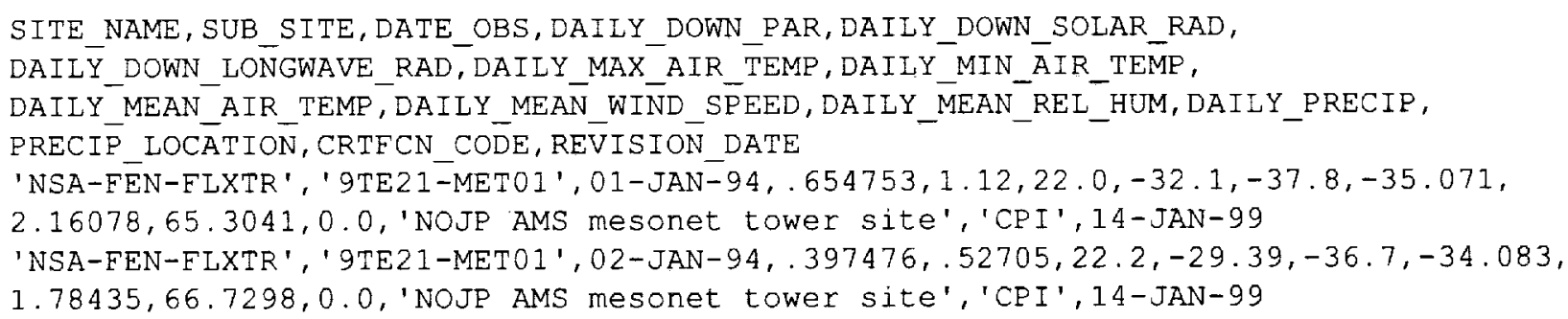

\section{Data Organization}

\subsection{Data Granularity}

The smallest unit of data tracked by BORIS was the data collected at a given site on a given date.

\subsection{Data Format(s)}

The Compact Disk-Read-Only Memory (CD-ROM) files contain American Standard Code for Information Interchange (ASCII) numerical and character fields of varying length separated by commas. The character fields are enclosed with single apostrophe marks. There are no spaces between the fields.

Each data file on the CD-ROM has four header lines of Hyper-Text Markup Language (HTML) code at the top. When viewed with a Web browser, this code displays header information (data set title, location, date, acknowledgments, etc.) and a series of HTML links to associated data files and related data sets. Line 5 of each data file is a list of the column names, and line 6 and following lines contain the actual data. 


\section{Data Manipulations}

\subsection{Formulae}

See Section 9.3.

\subsubsection{Derivation Techniques and Algorithms \\ None given.}

\subsection{Data Processing Sequence}

\subsubsection{Processing Steps}

Half-hourly meteorological data were derived from 1994 TF and AMS mesonet measurements. These data often contained temperature, wind, and humidity data at one or more heights. When data at more than one height were available, data were taken from the upper height that corresponded most closely with the top of the canopy or the upper level at which water and $\mathrm{CO}_{2}$ fluxes were measured. No attempt was made to adjust the data to account for differences in measurement heights.

Full-year half-hourly data files for each tower site were created by placing several adjacent tower site data files together in series. Missing values were then selected from adjacent data files with complete data for the same time period. Preceding data were always favored first in the selection process. The following series were used to create complete data files for each tower site:

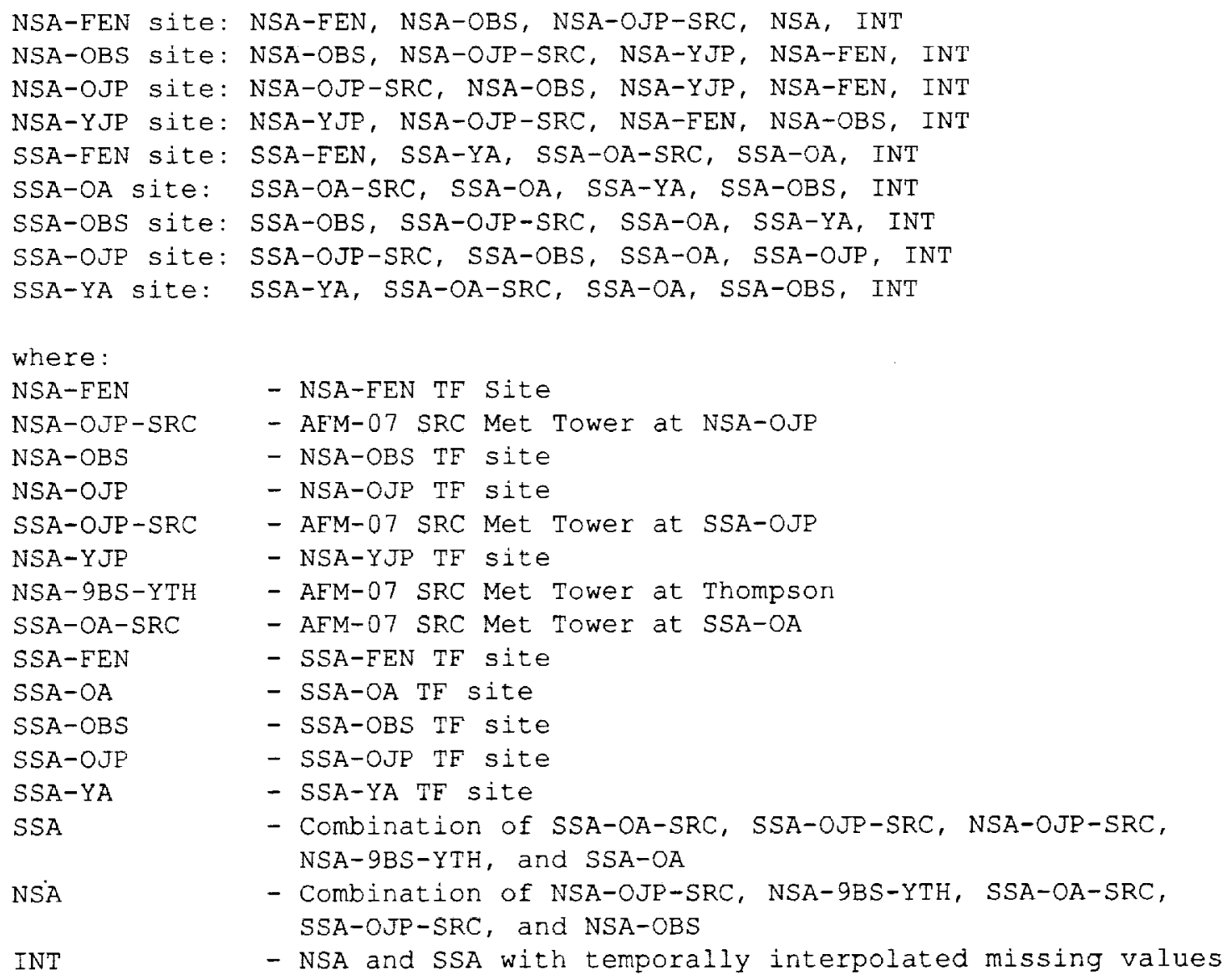

- Combination of SSA-OA-SRC, SSA-OJP-SRC, NSA-OJP-SRC, NSA-9BS-YTH, and SSA-OA

- Combination of NSA-OJP-SRC, NSA-9BS-YTH, SSA-OA-SRC, SSA-OJP-SRC, and NSA-OBS

- NSA and SSA with temporally interpolated missing values 


\subsubsection{Processing Changes}

None given.

\subsection{Calculations}

LW measurement data from NSA-OJP-SRC and SSA-OJP-SRC were used to represent longwave radiation characteristics for tower sites in the BOREAS NSA and SSA, respectively. Missing values were estimated using a multiple linear regression fit between measured longwave radiation, estimated clear-sky longwave radiation, and relative humidity:

$$
\text { Iw.est }=80.3855+0.7521 * \text { Iw.clr }+0.4525 * \mathrm{RH}
$$

where: $\quad$ lw.est $=$ estimated $\mathrm{l} w$ irradiance $\left(\mathrm{W} / \mathrm{m}^{2}\right)$

lw.clr = estimated clear-sky lw irradiance $\left(\mathrm{W} / \mathrm{m}^{2}\right)$

$\mathrm{RH}=$ measured relative humidity $(\%)$

lw.clr was estimated from air temperature and relative humidity measurements using an approach described by Marks and Dozier (1979).

\subsubsection{Special Corrections/Adjustments}

None.

\subsubsection{Calculated Variables}

See Section 9.3.

\subsection{Graphs and Plots \\ None given.}

\section{Errors}

\subsection{Sources of Error}

Only general error checking has been done to the data to eliminate unreasonably extreme data values. No attempt has been made to identify and correct for errors caused by location, terrain, or instrument elevation differences between TF sites. Analyses of meteorological data showed that daily temperature and humidity differences between TF sites were small within the NSA and SSA, indicating that terrain effects were generally minimal. Differences in daily data as a result of sensor height differences were also found to be small. The daily magnitudes of precipitation between sites, however, tended to be quite variable.

Greater than $80 \%$ of the temperature, precipitation, and humidity data for SSA-OJP, SSA-OA, and NSA-OJP sites were measured at those locations. At the other sites, between $20 \%$ and $40 \%$ of air temperature and humidity measurements and from $40 \%$ to $60 \%$ of precipitation measurements were actually obtained from those respective locations for 1994. Most of these data were collected during the growing season. The majority of the data during the winter months were obtained from the AMS mesonet sites, which ran over the entire year.

\subsection{Quality Assessment}

\subsubsection{Data Validation by Source}

General error checking has been done to the data to eliminate unreasonably extreme data values. 


\subsubsection{Confidence Level/Accuracy Judgment}

See Section 10.

\subsubsection{Measurement Error for Parameters}

None given.

\subsubsection{Additional Quality Assessments}

None given.

\subsubsection{Data Verification by Data Center}

Data were examined for general consistency and clarity.

\section{Notes}

11.1 Limitations of the Data None given.

11.2 Known Problems with the Data None given.

11.3 Usage Guidance None given.

11.4 Other Relevant Information None given.

\section{Application of the Data Set}

This data set can be used to study the meteorological conditions of the boreal forest.

\section{Future Modifications and Plans}

None given.

\section{Software}

\subsection{Software Description} None given.

14.2 Software Access

None given. 


\section{Data Access}

The daily surface meteorological data are available from the Earth Observing System Data and Information System (EOSDIS) Oak Ridge National Laboratory (ORNL) Distributed Active Archive Center (DAAC).

\subsection{Contact Information}

For BOREAS data and documentation please contact:

ORNL DAAC User Services

Oak Ridge National Laboratory

P.O. Box 2008 MS-6407

Oak Ridge, TN 37831-6407

Phone: (423) 241-3952

Fax: (423) 574-4665

E-mail: omldaac@ornl.gov or ornl@eos.nasa.gov

\subsection{Data Center Identification}

Earth Observing System Data and Information System (EOSDIS) Oak Ridge National Laboratory (ORNL) Distributed Active Archive Center (DAAC) for Biogeochemical Dynamics http://www-eosdis.oml.gov/.

\subsection{Procedures for Obtaining Data}

Users may obtain data directly through the ORNL DAAC online search and order system [http://www-eosdis.ornl.gov/] and the anonymous FTP site [ftp://www-eosdis.oml.gov/data/] or by contacting User Services by electronic mail, telephone, fax, letter, or personal visit using the contact information in Section 15.1.

\subsection{Data Center Status/Plans}

The ORNL DAAC is the primary source for BOREAS field measurement, image, GIS, and hardcopy data products. The BOREAS CD-ROM and data referenced or listed in inventories on the CD-ROM are available from the ORNL DAAC.

\section{Output Products and Availability}

\subsection{Tape Products}

None.

\subsection{Film Products}

None.

\subsection{Other Products}

These data are available on the BOREAS CD-ROM series. 


\section{References}

\subsection{Platform/Sensor/Instrument/Data Processing Documentation None given.}

\subsection{Journal Articles and Study Reports}

Marks, D. and J. Dozier. 1979. A clear-sky longwave radiation model for remote alpine areas: Archiv fur Meteorologie Geophysik und Bioklimatologie, ser. B, no. 27, p. 159-187.

Newcomer, J., D. Landis, S. Conrad, S. Curd, K. Huemmrich, D. Knapp, A. Morrell, J. Nickeson, A. Papagno, D. Rinker, R. Strub, T. Twine, F. Hall, and P. Sellers, eds. 2000. Collected Data of The Boreal Ecosystem-Atmosphere Study. NASA. CD-ROM.

Sellers, P. and F. Hall. 1994. Boreal Ecosystem-Atmosphere Study: Experiment Plan. Version 1994-3.0, NASA BOREAS Report (EXPLAN 94).

Sellers, P. and F. Hall. 1996. Boreal Ecosystem-Atmosphere Study: Experiment Plan. Version 1996-2.0, NASA BOREAS Report (EXPLAN 96).

Sellers, P., F. Hall, and K.F. Huemmrich. 1996. Boreal Ecosystem-Atmosphere Study: 1994 Operations. NASA BOREAS Report (OPS DOC 94).

Sellers, P., F. Hall, and K.F. Huemmrich. 1997. Boreal Ecosystem-Atmosphere Study: 1996 Operations. NASA BOREAS Report (OPS DOC 96).

Sellers, P., F. Hall, H. Margolis, B. Kelly, D. Baldocchi, G. den Hartog, J. Cihlar, M.G. Ryan, B. Goodison, P. Crill, K.J. Ranson, D. Lettenmaier, and D.E. Wickland. 1995. The boreal ecosystem-atmosphere study (BOREAS): an overview and early results from the 1994 field year. Bulletin of the American Meteorological Society. 76(9):1549-1577.

Sellers, P.J., F.G. Hall, R.D. Kelly, A. Black, D. Baldocchi, J. Berry, M. Ryan, K.J. Ranson, P.M. Crill, D.P. Lettenmaier, H. Margolis, J. Cihlar, J. Newcomer, D. Fitzjarrald, P.G. Jarvis, S.T. Gower, D. Halliwell, D. Williams, B. Goodison, D.E. Wickland, and F.E. Guertin. 1997. BOREAS in 1997: Experiment Overview, Scientific Results and Future Directions. Joumal of Geophysical Research 102(D24): 28,731-28,770.

\subsection{Archive/DBMS Usage Documentation None.}

\section{Glossary of Terms}

None given. 


\section{List of Acronyms}

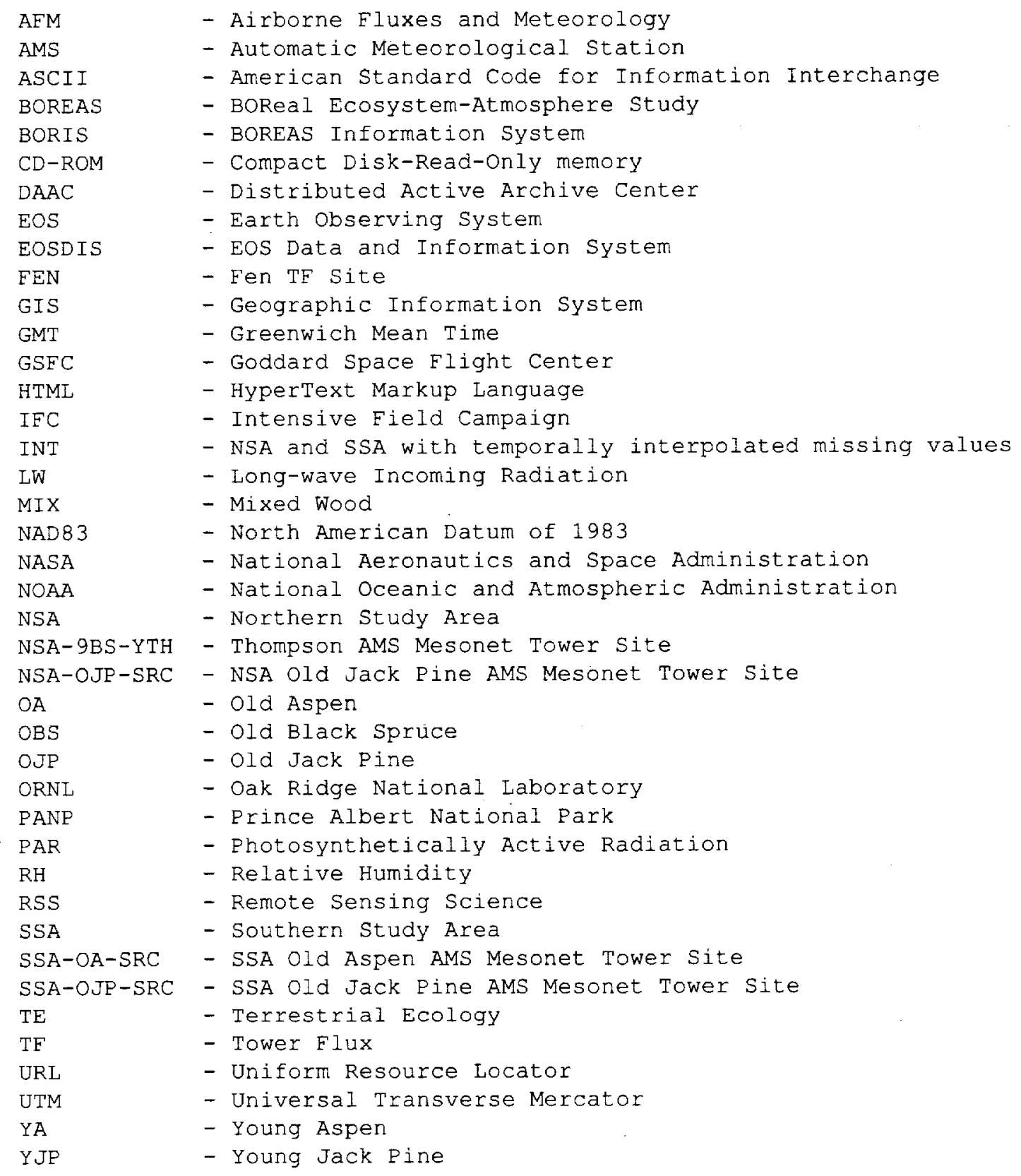




\section{Document Information}

20.1 Document Revision Date

Written: 08-May-1996

Last Updated: 30-Aug-1999

20.2 Document Review Date(s)

BORIS Review: 16-Oct-1997

Science Review:

\subsection{Document ID}

None.

\subsection{Citation}

When using these data, please include the following acknowledgment as well as citations of relevant papers in Section 17.2:

John Kimball of the University of Montana.

If using data from the BOREAS CD-ROM series, also reference the data as:

Running, S. and J. Kimball, "Simulation of Boreal Ecosystem Carbon and Water Budgets: Scaling from Local to Regional Extents." In Collected Data of The Boreal Ecosystem-Atmosphere Study. Eds. J. Newcomer, D. Landis, S. Conrad, S. Curd, K. Huemmrich, D. Knapp, A. Morrell, J. Nickeson, A. Papagno, D. Rinker, R. Strub, T. Twine, F. Hall, and P. Sellers. CD-ROM. NASA, 2000.

Also, cite the BOREAS CD-ROM set as:

Newcomer, J., D. Landis, S. Conrad, S. Curd, K. Huemmrich, D. Knapp, A. Morrell, J. Nickeson, A. Papagno, D. Rinker, R. Strub, T. Twine, F. Hall, and P. Sellers, eds. Collected Data of The Boreal Ecosystem-Atmosphere Study. NASA. CD-ROM. NASA, 2000.

\subsection{Document Curator}

\subsection{Document URL}





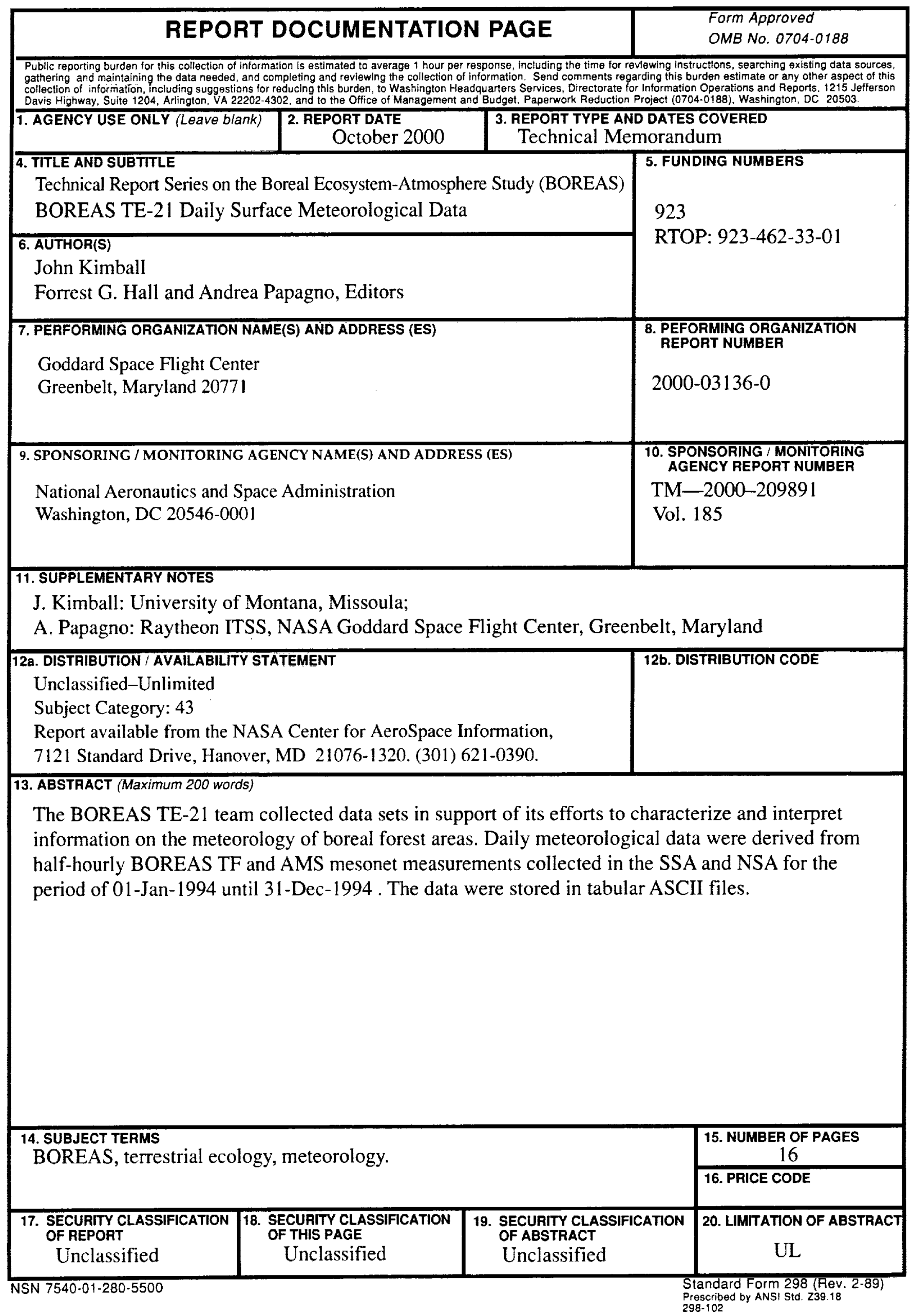

